\title{
介護プロセスの計測と記述
}

\author{
三輪 洋靖*1, 渡辺 健太郎 ${ }^{* 1}$

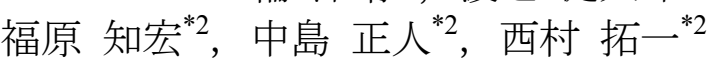

\section{Measurement and description of nursing-care service process}

\author{
Hiroyasu MIWA*1, Kentaro WATANABE*1, \\ Tomohiro FUKUHARA $^{* 2}$, Masato NAKAJIMA ${ }^{* 2}$ and Takuichi NISHIMURA ${ }^{* 2}$ \\ ${ }^{{ }_{1},{ }^{* 2}}$ Center for Service Research, National Institute of Advance Industrial Science and Technology (AIST) \\ AIST Waterfront 3F, 2-3-26 Aomi, Koto-ku, Tokyo 135-0064, Japan
}

Received 11 April 2014

\begin{abstract}
Employees at nursing-care facilities co-operate with each other and provide nursing-care service according to care plans designed to meet residents' physical condition and needs. Traditionally, improvement of service productivity in nursing-care service has been based on experience and inspiration of managers and employees. Engineering methods to achieve improvement is a relatively new and necessary approach. In this paper, the authors collaborated with eight nursing-care facilities, and developed engineering methods to achieve improvement of their service process and service productivity. At first, we classified employees' behaviors into a three-layer structure consisting of "service type", "purpose / situation" and "operation", and developed task classification for nursing-care service which could express 455 employees' states. We then described nursing-care service process as transition of employees' state with eight properties; "id", "start time", "end time", "task", "place", "target resident", "cost" and "detailed information". Finally, we measured behaviors of 20 employees at four nursing-care facilities to evaluate the task classification for nursing-care service proposed in this paper, and confirmed that it covered $96.9 \%$ of their behaviors. The cover rate was enough high for visualization of nursing-care service process. In addition, we visualized the nursing-care service process of 15 employees at a nursing-care facility with "time-line mode" and "statistical mode". We also confirmed that our proposed methods were effective to visualize the nursing-care service process and to improve service productivity in the service field.
\end{abstract}

Key words : Service engineering, Nursing-care service, Service process, Task classification, State transition

\section{1. 緒言}

日本における介護サービスの特徵を大きく分類すると, 高齢者が専用の施設に住み, 主にその施設内で介護少 ービスを受ける施設介護サービス，自宅で生活する高齢者が介護サービスを受ける訪問介護サービス，高齢者が 専用の施設に通い，その施設内で介護サービスを受ける通所サービスの 3 種類に大きく分類される. 2012 年にお ける各サービスの施設数は, 介護老人福祉施設(特別養護老人ホーム)や特定施設入居者生活介護施設(介護付有料 老人ホーム)に代表される施設介護サービスが 16,221 事業所, 訪問介護サービスが 40,075 事業所, 通所介護, 通 所リハビリテーションを合わせた通所介護サービスは 41,130 事業所に達しており, その総数は年々増加し続けて いる(厚生労働省, 2013).

これらの介護サービスでは，サービス利用者である高齢者のニーズや身体状態に基づいて作成された介護計画

No.14-00207 [DOI: 10.1299/transjsme.14-00207], J-STAGE Advance Publication date : 16 January, 2015

${ }^{* 1}$ 正員, (独) 産業技術総合研究所 サービス工学研究センター（广135-0064 東京都江東区青海 2-3-26）

${ }^{* 2}$ (独) 産業技術総合研究所 サービス工学研究センター

E-mail of corresponding author: h.miwa@aist.go.jp 
に基づき，介護士や看護師，介護支援専門員といった複数の専門的知識，スキルを持った従業員が相互に連携し ながら提供される，一般に，介護施設従業員の業務量は多く，人命に関わる業務でもあることから，従業員の心 身にかかる負担は高い，一方で，経営的観点からは限られた人的資源で，最大限のサービスを提供することが望 ましいため，サービス生産性が向上寸るように，サービスを設計することが求められている.

ここで, サービス生産性とは価值創出に使用される資源の割合を指し, 分母に相当する業務効率の改善もしく は分子に相当する付加価值の向上, 新規ビジネスの創出によって改善することが知られている(サービス産業のイ ノベーションと生産性に関する研究, 2007). サービスの設計やサービス生産性に関する研究は, サービス工学分 野で盛んに行われており, 設計工学の手法を用いたサービスのモデル化手法やサービスの設計支援手法, IT シス テムを用いた顧客支援, 従業員支援技術などが研究されている(下村他, 2005; 坂尾他, 2005; 原他, 2008; Takenaka, et al., 2012). これに対し, 介護サービスのように顧客接点時間が長いサービスでは, 管理者だけでなく, サービ ス現場の「人」である顧客や従業員の関わり方が重要となる，そこで，筆者らは，サービス現場の「人」を考慮 したサービスの設計, 評価手法が必要と考えた. そして, サービス現場の顧客や従業員の行動の計測と分析に基 づくサービスプロセスのモデルを構築, 対話的なシミュレーション技術などにより効率的なサービスを再設計し, それを現場に適用するという最適設計ループを繰り返す「人」起点のサービス工学を推進してきた(持丸, 2011).

介護サービスの場合, 1 つのサービス現場に多くの従業員と顧客が関わるため, サービスプロセスは複雑であ る.したがって, 介護サービスのサービス生産性の向上には, 現状のサービス, すなわち, サービスプロセスの 正確な理解とその結果に基づいた業務効率の改善やサービスプロセスの再設計が必要であると筆者らは考えてい る. しかし, 介護サービスでは, これらの改善は経営者や一部の従業員の経験と勘に基づいて行われており, 標 準的記述手法や工学的手法が確立されていなかった。 そこで, 筆者らは「サービス提供における人, モノ, 情報, 道具，時間，カネの一連の動き・流れ」をサービスプロセスと定義し，介護サービスにおけるサービスプロセス を「介護プロセス」と名付けた(Miwa, et al., 2012; 三輪他，2012). そして，介護プロセスを可視し，定量的に分 析可能と寸るため, 介護プロセスの計測と記述手法を提案することを本研究の目的とした．本稿では第 2 章で介 護プロセスの計測手法について, 第 3 章で介護プロセスの記述手法について述べる. 第 4 章で提案手法の評価実 験を行い，第 5 章は結言である.

\section{2. 介護施設従業員の行動分類コード}

介護プロセスの中心の 1 つに従業員の行動がある．従業員間，施設間など多条件間で介護プロセスを比較する ためには，介護施設従業員の状態や行動を計測し，それを統一的な方法で記述する必要がある．本章では，従業 員の行動計測と介護施設従業員の行動分類コードについて述べる.

\section{$2 \cdot 1$ 従業員の行動計測}

介護プロセスに限らず, 従業員の状態や行動を計測する手法としては, 従業員自身もしくは第 3 者による観察 によって行動を記録寸るタイムスタディが用いられることが多い.タイムスタディとは作業測定法の一種であり, Taylor が提唱した科学的管理法による Time study と Gilbreth が研究した Motion studyをべースに産業工学の分野に おいて構築されてきた. 現在では両者が統合された Time and motion studyが一般的となっており (Pigage and Tucker, 1954; 笠原他, 2004a), 本稿ではこれらをまとめてタイムスタディと呼ぶ.

主なタイムスタディの計測手法には，連続観測法とワークサンプリング法がある．また，それぞれの計測手法 について, 第三者が対象者の行動を観察して記録する他計式と, 計測対象者自身が自己報告によって記録する自 計式の 2 種類がある. いずれの方法であっても, 時間とともに変化する対象者の行動を記録することで, 対象者 がどのような行動にどれだけの時間を費やしているかを計測・分析する.

タイムスタディで対象者の行動を記録する典型的な方法は, 計測者が手書きで観察ノートに対象者の行動を記 録する方法である.このとき, 観察ノートへの記述段階では, 用語の標準化を行わないことが多い. この方法で は，人間の高い認知能力を用いるため，対象者の行動を正確に認識でき，計測中の手書きによる記録は簡便とい う長所がある. しかし，計測後に観察結果の行動分類やデジタル化が必要であり，分析に時間がかかるのが短所 である (表 1, Time and motion study with hand-writing record 参照). この短所を補うため, モバイルデバイス上で 
稼働するタイムスタディ支援ツールも開発されているが，ツールへの慣れが必要であり，手書き記録と比べると 使いや寸さが劣るケースが多い (表 1, Time and motion study with support system 参照).

従来，タイムスタディは，作業時間の短縮が生産コストの低下や生産性の向上に繋がる生産管理の現場で用い られることが多かったが，最近では飲食や看護サービス等，サービス産業での適用事例も増えている(笠原他， 2004b; 松波, 2010). 介護サービスにおけるタイムスタディ調查の事例としては, 要介護認定調査検討会がケア を必要する高齢者約 5000 人について, どれくらいのケアが提供されているかを 1 分間タイムスタディという方法 で計測し，高齢者介護の実態を調査している(要介護認定調査検討会，2007)。また，國定らは介護士がどの業務 にどの程度の時間を費やしているかを，笠原ら，清水らは，タイムスタディによる看護師の行動計測を行ってい る(國定，2010；笠原，2010；清水他，2010).

一方で，加速度計やジャイロなどのセンサを組み合わせた小型の装着型センサを用いて従業員の位置や行動を 推定する手法や, 施設内にカメラ, マイクを設置し, 映像と音声から従業員の状態を推定する手法など, 行動計 測を自動化する研究も進められている. 蔵田らはPDRPlus を開発しており, 対象者の位置の時空間情報を自動的 に記録し，体動データから行動の識別を行っている(Kourogi, et al., 2010; 蔵田, 天目，2013). 装着型センサの最 大の特徵は, 記録が自動化され観察者が不要となるため, タイムスタディよりも記録が簡便であり, 計測コスト を大幅に削減できることと，多くの従業員の計測を同時かつ継続的にできることである．しかし，行動認識の精 度は人間の認知能力と比較すると低く, 識別できる行動の種類が少ないのが現状である (表 1, Automatic measurement with wearable sensors 参照). 表 1 にタイムスタディ(手書き記録, 記録サポートシステム)と装着型セ ンサによる自動記録の特徵をまとめた.

\section{$2 \cdot 2$ 介護施設従業員の行動分類コードの構築}

行動計測の結果から介護プロセスを組み立て，施設間，従業員間での比較を可能にするためには，一連の行動 を分節化し，それぞれを適切に分類，記述する行動分類コードが必要である．また，前述したように従業員の行 動計測には多様な計測手法が考えられ, 今後も計測手法の多様化が進むと考えられるため, 行動分類コードには, 計測技術に対する依存性が低いことが望ましい.

行動分類コードとしては，国際生活機能分類(ICF, International Classification of Functioning, Disability and Health) が生活行動を分類している(世界保健機構, 2008). しかし，ICF は介護サービス利用者の行動や身体状態を記述す ることを主目的としており，生活行動とは異なる介護施設従業員の業務を記述するには不十分である．介護士の 行動分類コードとしては, 厚生労働省・要介護認定調查検討会が平成 18 年第 2 回要介護認定調查検討会にて作成 したケアコードがある(要介護認定調査検討会, 2007). ケアコードは, 大分類, 中分類にて, 主要な定型的な身 体的介助, 間接介助等が列挙されており, 介護士用の行動分類コードの基礎といえる. しかし，介護士を想定し たケアコードは看護, 機能訓練, 介護支援サービスを提供している看護師や介護支援専門員などが対象となって おらず，本研究で目指している業務改善のための介護プロセスの可視化には不十分な点もあった. 介護に近い分 野では, 日本看護科学学会が看護行為の整理目的として看護行為用語分類を(日本看護科学学会, 2005), 沼崎ら が病棟看護師用のタイムスタディに用いる看護業務分類表を提案している(沼崎他，2004). 看護業務分類表も看 護業務を 3 階層に分類しており, 看護業務の行動分類コードの基礎と位置づけられている. 以上のように, 特定 の職種に関する行動分類コードや行動調查の研究例はあるが，介護施設従業員の行動を幅広く網羅し，サービス 生産性の改善や, 介護プロセスの可視化を目的とした行動分類コードは定義されていない. そこで，筆者らは介 護プロセスの可視化に最適な介護施設従業員の行動分類コードを新規に構築した.

Table 1 Comparison of time and motion study method

\begin{tabular}{c|c|c|c}
\hline \hline Method & $\begin{array}{c}\text { Time and motion study } \\
\text { with hand-writing record }\end{array}$ & $\begin{array}{c}\text { Time and motion study } \\
\text { with support system }\end{array}$ & $\begin{array}{c}\text { Automatic measurement } \\
\text { with wearable sensors }\end{array}$ \\
\hline Recognition accuracy & Good & Good & Bad \\
\hline Ease of recording & Easy & Difficult & Very easy \\
\hline Post-measurement process & Hard & Easy & Easy \\
\hline
\end{tabular}


行動分類コードの構築にあたっては, 介檴老人保健施設 和光苑, 介護付有料老人ホーム スーパー・コート平 野, 有料老人ホーム スーパー・コート東大阪みと, 高齢者住宅 スーパー・コート南花屋敷の 4 施設にご協力を 頂き，従業員の行動観察およびインタビュー調査を行うことで，介護施設従業員が実施する行動を抽出した．和 光苑では入所サービスと通所リハビリテーションを，スーパー・コート平野では入所サービスを提供している. また，スーパー・コート東大阪みと，および，スーパー・コート南花屋敷では，近隣に設置された訪問介護事業 所による訪問介護サービスを入居者が利用しており，国内の代表的介護サービスである施設介護サービス，訪問 介護サービス, 通所介護サービスにおける従業員の行動を網羅した. 行動観察は上記施設に勤務している介護士, ヘルパー，看護師，介護支援専門員，作業療法士，管理栄養士の合計 36 名を対象とし，2010 年 8 月〜2012 年 10 月に実施した。調查方法は，筆者らが業務を邪魔しないように調査対象者に同行し，目視の連続観測法による他 計式タイムスタディによって行動を観察し，観察ノートにその行動を記録した.

その結果, 介護施設従業員の行動として 145 種類の行動が観察された。 そこで, ケアコードおよび看護師業務 分類表の分類体系を参考に階層構造で, 上位から下位へと行動の粒度が細かくなり, 各階層の粒度が揃うように 介護施設従業員の行動を分類した. さらに, 行動分類の結果について, 調查対象者を含む協力施設従業員に提示 し，その妥当性に関して意見交換を繰り返すことで，行動分類コードとして体系化した．そして，上位から第 1 階層が「サービスの種類」, 第 2 階層が「目的・状況」, 第 3 階層が「行動」となる 3 層構造で行動を分類した.

まず, 第 1 階層であるサービスの種類としては, 主にサービスの専門性をもとに分類し, 介護, 看護, リハビ リテーション, 介護支援, 食事・栄養, 間接業務, 業務外の 7 項目に分類し, 従業員の行動がどのサービスのた めに行われたかを記述した. 介護, 看護, リハビリテーション, 介護支援, 食事・栄養では, 介助動作や医療処 置などサービス利用者への直接的に提供されるサービスやそのための準備などの行動が分類され，間接業務には 会議など施設運営上に必要な行動が，業務外には休賃など業務時間外の行動が分類される．また，いずれにも分 類不可能な特殊事例を示す「その他の業務」と，行動計測における不具合によって計測できなかったことを示寸 「エラー」を追加した．次に，第 2 階層である目的・状況では，行動を実施するための目的や行動を実施したと きの状況をもとに分類し, 適切なサービスの種類の下に配置した. そして, 介護 12 項目(起床・就寝, 体位変換, 更衣・整容, 移動, 排泄, 食事, 清潔, 環境整備, 洗濯, 買物, レクリエーション, 送迎), 看護 5 項目(医療処 置, 薬品管理, バイタル測定, 診察, 身体機能への直接的働きかけ), リハビリテーション 3 項目(理学療法, 作 業療法, 言語聴覚療法), 介護支援 1 項目(ケアプラン), 食事・栄養 3 項目(栄養管理, 給食, 衛生管理), 間接業 務 3 項目(移動，会議，清掃)，業務外 1 項目(休嚊), エラー1 項目(エラー)に分類した. そして, 第 3 階層である 行動には, 行動観察, インタビュー調查によって得られた 124 種類の行動を配置した.

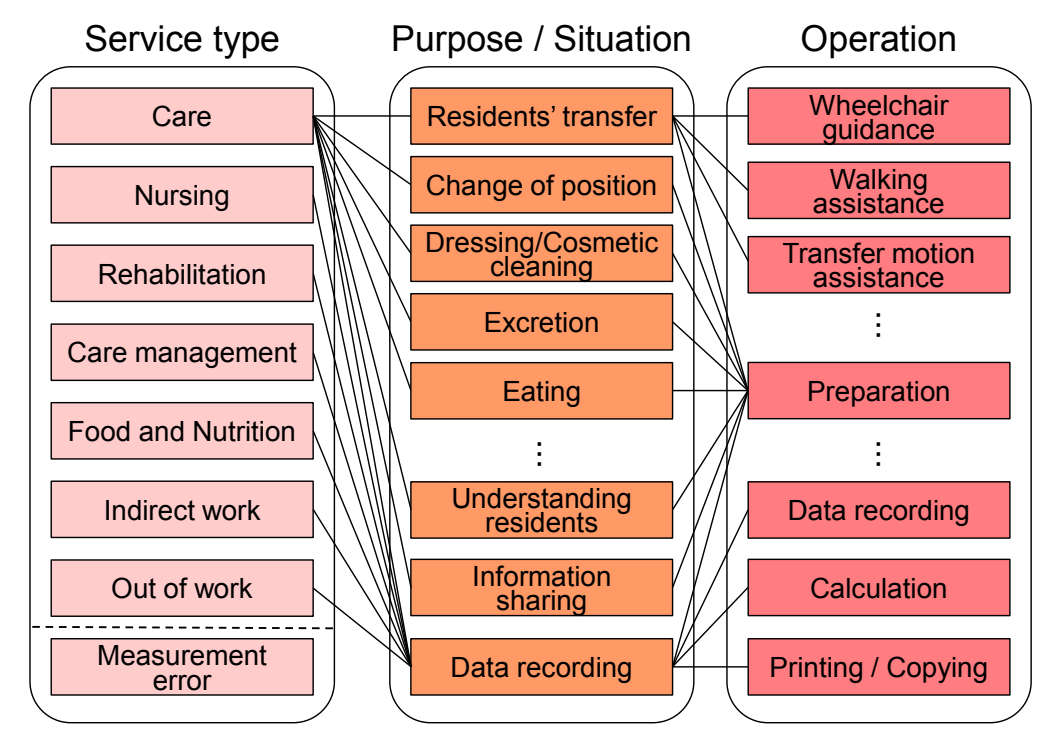

Fig. 1 Three-layer structure of task classification for nursing-care service. 145 employee's behaviors were classified into a three-layer structure consisting of "service type", "purpose / situation" and "operation". And, it could express 455 employees' states. 
残りの 21 種類の行動は，従業員間の情報共有や作業記録，準備・片付けなど，特定のサービスの種類だけでは なく, 複数のサービスの種類に関して生じる行動であった. そこで, 全てのサービスの種類に対して,「利用者理 解」「情報共有」「記録作成」「確認」「来客対応」の 5 項目を目的・状況として追加することで，これらの 5 項目 がどのサービスのために実施されたかをより正確に記述できるようにした．同様にして，複数の目的・状況に関 して生じる行動として「準備・片付け」「手洗い」の 2 項目を行動に追加した．また，「その他のサービス」とい う項目を目的・状況に,「その他」という項目を行動に加えることで, 分類不可能な特殊事例や新しい行動に備え ることとした，そして，各層の項目を組み合わせることで，介護施設従業員の状態として 455 種類の状態を表現 可能にした.

最後に, 本行動分類はサービス現場での使用を想定しているため, 各項目の名称には介護施設従業員が通常 業務で使用する用語を用い，現場の従業員が理解しやすいものとした，そして，分類されたすべての行動に対 して, 第 1 階層英字 1 桁, 第 2 階層数字 2 桁, 第 3 階層数字 2 桁の合計 5 桁の行動分類コードを付与するこ とで, 介護施設従業員の行動分類コードを構築した. 介護施設従業員の行動分類コードの基本構造として, 図 1 に介護施設従業員の行動分類コードの一部を抜粋する. 図 1 では, 左から, 「サービスの種類」,「目的・状況」,

「行動」による階層構造を構築しており, 結線の有無は項目間の上下関係の有無を表している. また, 付表 1〜5 に介護施設従業員の行動分類コードの全コードを示す.

\section{3. 介護プロセスの記述}

人起点サービスである介護サービスではサービス提供者-サービス利用者間の接点が多い. 筆者らが, 介護施設 従業員の行動がどのように変化していったかを行動観察によって分析したところ, 図 2 に示した 6 種類の遷移パ ターンが観察された. もっとも多かったのは, 図 2(a)に示すような特定の行動から別の行動へと順番に実行して いく場合で「独立プロセス」と名付けた。しかし，介護プロセスでは，図 2(b) (e)のように特定の行動中に別の 行動を同時に実行する場合や，図 2(f)のように特定の行動を一時的に保留し，別の行動を実行したのちに元の行 動に戻る場合も観察された。筆者らは前者を「並行プロセス」, 後者を「割り込みプロセス」と名付けた.また, 実業務ではこれらの 6 種類の遷移パターンが組み合わさって実行され，一連のサービスであっても常に同じ手順

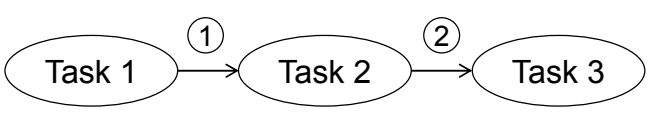

(a) Pattern 1: Single process

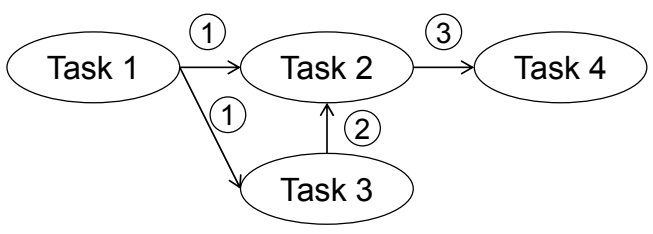

(c) Pattern 3: Parallel process (first parallel)

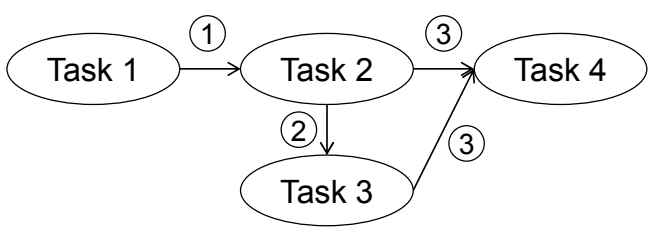

(e) Pattern 5: Parallel process (last parallel)

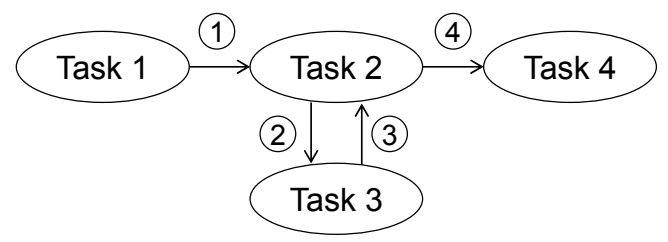

(b) Pattern 2: Parallel Process (partially parallel)

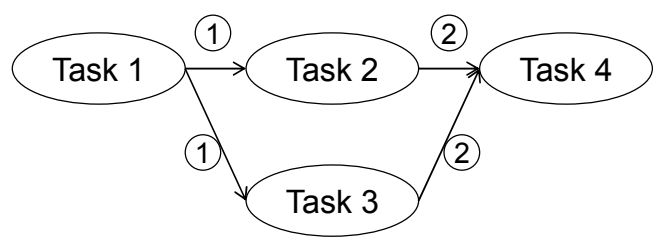

(d) Pattern 4: Parallel process (fully parallel)

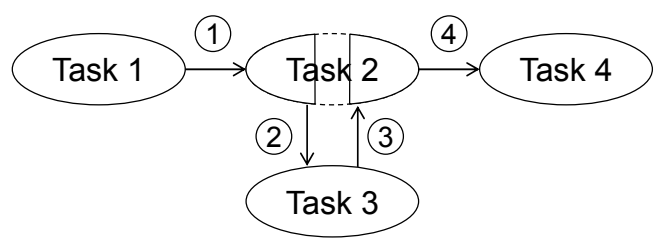

(f) Pattern 6: Interruption process

Fig. 2 State transition patterns in the nursing-care service process. The nursing-care service process included three features; concurrency, irregularity and wide variety. 
で害行されるとは限らなかった，つまり，介護プロセスの特徵には，(11 人のスタッフが複数の作業を同時に実 行する「並行性」，(2)顧客・従業員からの要求が多様で割り込みが不定である「不定性」，(3)顧客属性によってプ ロセスが変化し，同一サービスを提供するのに複数の方法が存在する「多様性」の 3 つ特徵があると言える.

介護サービスに限らず，サービスプロセスを記述・可視化する手法としては，フローチャートやガントチャー ト，BPMN (Business Process Model Notation)に代表される生産プロセスの手法を用い，時系列に沿った従業員の行 動や業務，状態の記述が試みられてきた(White, 2004). 原らはこれらの記述手法をサービスプロセスに適用し， サービスプロセスを可視化している(原他, 2009). また, Event-driven Process Chains を用いた割り込み表現を含む ビジネスプロセスモデリング(van der Aalst, 1999; Scheer and Schneider, 2006)や，Scene Transition Nets を用いたサー ビスプロセスのシミュレーション手法(Tateyama, et al., 2012)なども提案されている. しかし, 従来手法では, 人起 点で多数の割り込みや並行作業が発生する介護プロセスの特徵を記述することが困難であった.

そこで，介護プロセスを記述するため，本研究では状態遷移による介護プロセスの記述手法を構築した。「人」 起点サービスの中心は「人」であることから，本手法では時系列ではなく，計測対象者の行動を起点とするとこ ろに特徴がある. そして,「人」の動きである行動を核として, 介護プロセスで流れる「モノ」,「情報」,「道具」, 「時間」，「カネ」に関する属性を付与し，それぞれの属性を持った行動を状態と定義した．そして，一連のサー ビスにおいて，遷移していく計測対象者の状態の集合を「介護プロセス」とし，複数の属性を持つ状態が時間や 環境，行動，対象者などの任意の条件に従って遷移することで介護プロセスを表現した. 図 3 に属性，状態，介 護プロセスの関係を示す.

さらに, ある状態から複数の状態への遷移を認めることで, 並行プロセスのような介護プロセスの並行性の記 述を実現し，遷移条件を時間以外にも設定することで，割り込みプロセスのような時間軸との依存性が低い遷移 条件による介護プロセスの記述，すなわち，介護プロセスの不定性の記述を実現した．また，一連のサービスに ついて, 複数の状態遷移手順を記述することで, 介護プロセスの多様性も記述可能とした. 以上より, 介護プロ セスが持つ「並行性」「不定性」「多様性」の 3 つの特徵を表現可能な介護プロセスの記述手法を構築できた.

具体的には，本論文では 8 属性を持つ状態の集合として介護プロセスを記述した．まず，タイムスタディなど の行動計測によって介護施設従業員の行動を詳細に計測し，行動分類コードを用いてその行動を記述する.ここ で得られた計測対象者の行動が核となり，介護プロセスの「人」要素を表す．次に，得られた行動ごとに「id」 「開始時刻」「終了時刻」「場所」「サービス対象者」「コスト」「詳細な作業内容」の属性を付与し，「行動」を含 めた 8 属性を持つ状態として, 計測対象者の状態を表現した。「開始時刻」「終了時刻」属性で介護プロセスにお ける「時間」の要素を,「場所」「サービス対象者」属性で「モノ」の要素を,「コスト」属性で「カネ」の要素を 表現している. 場所, サービス対象者はある固定された対象と考え, 広い意味で「モノ」の一部と捉えた. また, 介護施設従業員の行動分類コードには道具の使用, 情報の伝達に関寸る行動が含まれている. そこで,「詳細な作 業内容」属性に定型化しにくい状況を記述することで，「道具」および「情報」の要素を表現した．そして，一連 のサービスにおいて, 変化していく従業員の状態の集合を「介護プロセス」とした. この 8 属性を持つ状態が時 間や環境，行動，対象者などの任意の条件に従って遷移することで介護プロセスは表現される.

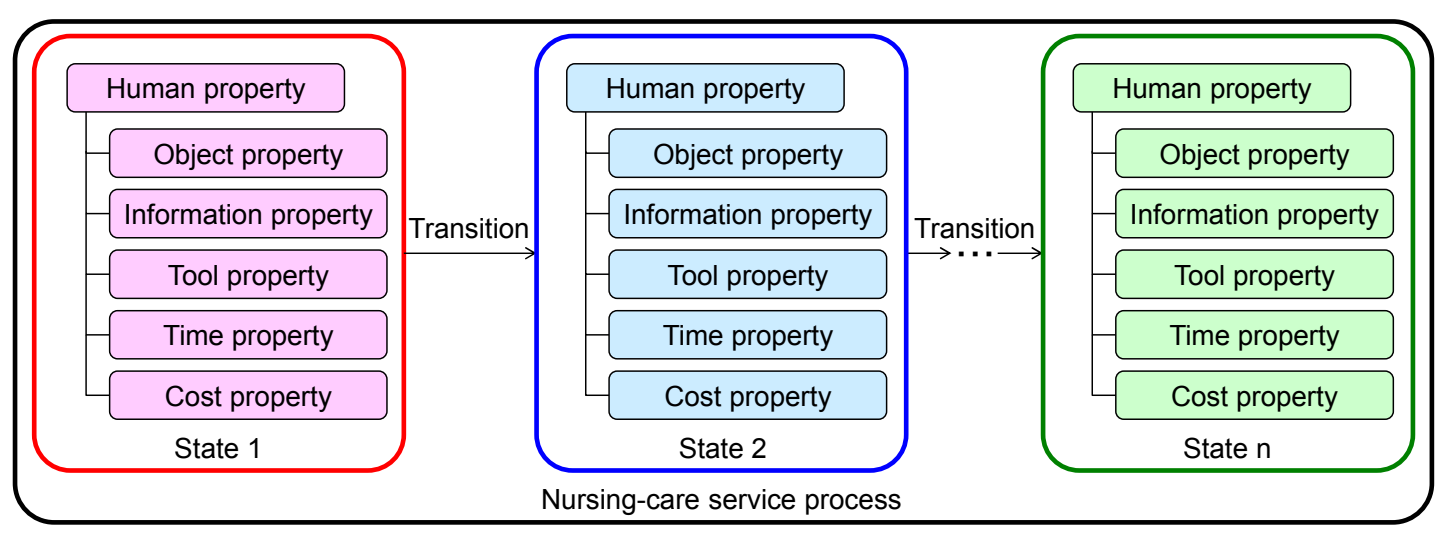

Fig. 3 Relation of properties, states and nursing-care service process. The nursing-care service process consists of states, and the states have human, object, information, tool, time and cost properties. 


\section{4. 評 価 実 験}

\section{$4 \cdot 1$ 介護施設従業員の行動分類コードの評価}

介護施設従業員の行動分類コードが介護施設従業員の行動の表現に有効であることを評価するため，介護施設 従業員に対する行動調査を実施した. 調査は, 介護付有料老人ホーム シルバーシテイ武蔵境, 特別養護老人ホー ム いづテラス, デイサービスセンター ひまわり，デイサービス ゆたかの 4 施設で実施し，各施設に勤務する介 護士，看護師，介護支援専門員，生活相談員，合計 20 名を対象とした。そして，筆者らが業務を邪魔しないよう に計測対象となる従業員に同行し，目視の連続観測法による他計式タイムスタディによって対象者の行動を観察 し，介護施設従業員の行動分類コードを用いて記録した.

Table 2 Experimental results about cover rate of the task classification code

\begin{tabular}{|c|c|c|c|c|c|}
\hline Service Type & Facility Name & Employees & $\begin{array}{l}\text { Number of total } \\
\text { behabior for a day }\end{array}$ & $\begin{array}{c}\text { Number of } \\
\text { categorized } \\
\text { behavior for a day }\end{array}$ & $\begin{array}{c}\text { Cover rate of task } \\
\text { classification code } \\
{[\%]}\end{array}$ \\
\hline \multirow{6}{*}{$\begin{array}{c}\text { Specialized } \\
\text { care house }\end{array}$} & \multirow{6}{*}{$\begin{array}{l}\text { Silver City } \\
\text { Musashisakai }\end{array}$} & Care worker & 752 & 720 & 95.7 \\
\hline & & Care worker & 444 & 436 & 98.2 \\
\hline & & Care worker & 182 & 180 & 98.9 \\
\hline & & Clean staff & 640 & 638 & 99.7 \\
\hline & & Nurse & 189 & 185 & 97.9 \\
\hline & & Receptionist & 503 & 492 & 97.8 \\
\hline \multirow{6}{*}{$\begin{array}{l}\text { Geriatric } \\
\text { welfare home } \\
\text { for the elderly }\end{array}$} & \multirow{6}{*}{ Izu Terrace } & Care manager & 118 & 115 & 97.5 \\
\hline & & Care worker & 566 & 549 & 97.0 \\
\hline & & Care worker & 494 & 490 & 99.2 \\
\hline & & Care worker & 496 & 484 & 97.6 \\
\hline & & Nurse & 477 & 475 & 99.6 \\
\hline & & Nurse & 492 & 487 & 99.0 \\
\hline \multirow{4}{*}{$\begin{array}{l}\text { Day care } \\
\text { service }\end{array}$} & \multirow{4}{*}{ Himawari } & Care worker & 698 & 665 & 95.3 \\
\hline & & Nurse & 341 & 337 & 98.8 \\
\hline & & Social worker & 322 & 316 & 98.1 \\
\hline & & Social worker & 462 & 447 & 96.8 \\
\hline \multirow{4}{*}{$\begin{array}{l}\text { Day care } \\
\text { service }\end{array}$} & \multirow{4}{*}{ Yutaka } & Care worker & 356 & 318 & 89.3 \\
\hline & & Care worker & 662 & 610 & 92.1 \\
\hline & & Nurse & 341 & 324 & 95.0 \\
\hline & & Social worker & 236 & 228 & 96.6 \\
\hline \multicolumn{3}{|c|}{ Average } & 439 & 425 & 96.9 \\
\hline
\end{tabular}

Table 3 Experimental Condition of nursing-care service process measurement at Wakouen

\begin{tabular}{c|c|c|c}
\hline \hline \multicolumn{2}{c|}{ Stage } & First stage & Second stage \\
\hline \multirow{2}{*}{ Period } & $2010 / 10 / 21-22$ & $2011 / 2 / 17-18$ \\
\cline { 2 - 4 } Number of target employees & Leader care worker & 1 & 2 \\
\cline { 2 - 4 } & Care worker & 2 & 2 \\
\cline { 2 - 4 } & Nurse & 1 & 2 \\
\cline { 2 - 4 } & Occupational therapist & 2 & 1 \\
\cline { 2 - 4 } & Care manager & 1 & 0 \\
\cline { 2 - 4 } & Dietician & 1 & 0 \\
\hline
\end{tabular}


その結果, 表 2 に示寸通り, 各施設の従業員は 1 日の勤務につき, 平均 439 の行動を行っていた. そのうち, 行動の種類が分類不能を示す「その他」にならず，介護施設従業員の行動分類コードで記述することができた行 動は平均 425 であった. つまり, 介護施設従業員の行動分類コードは介護施設従業員の行動の 96.9 \%を網羅して おり, 本研究で提案した介護施設従業員の行動分類コードが介護施設従業員の行動を記述するのに十分な性能を 有していることを確認できた.

\section{$4 \cdot 2$ 介護プロセスの計測と可視化}

介護施設従業員の行動分類コード, 状態遷移による介護プロセスの記述の有用性を評価するため, 介護サ ービスの提供現場である介護施設にて，介護プロセスの計測と可視化を行った．介護プロセスの計測は，介 護老人保健施設 和光苑の協力のもと, 前期・後期の 2 回に分け, 表 3 に示した 15 人を対象として実施した. そして, 筆者らが業務を邪魔しないように計測対象となる従業員に同行し, 目視の連続観測法による他計式 タイムスタディによって対象者の行動を観察し, 調查対象者の行動の開始時刻, 終了時刻, 場所, 行動, 誰と 一緒かを可能な限り詳細に記録した. 行動の記録には介護施設従業員の行動分類コードを用いた. 計測後, 提 案手法を用いて介護プロセスを構築し, 筆者らが「タイムライン表示」「統計表示」と呼ぶ 2 種類の方法で可 視化した.

タイムライン表示とは, 横軸に時間軸を, 縦軸に介護プロセス任意の属性を設定し, 設定した属性が生じ た時間にマークを付ける方法で, 時間軸に沿った従業員の介護プロセスの遷移を可視化した. 図 4 に介護士 の介護プロセスにおける行動の目的・状況層に関する遷移をタイムライン表示で示す．ここで，2つ以上の 状態について，その「開始時刻」「終了時刻」属性が重なる場合，同時刻に複数の状態にマークがつくことにな る.これは, 介護プロセスが「並行プロセス」へと遷移し, 複数の行動を同時に実行していることを示す.また,

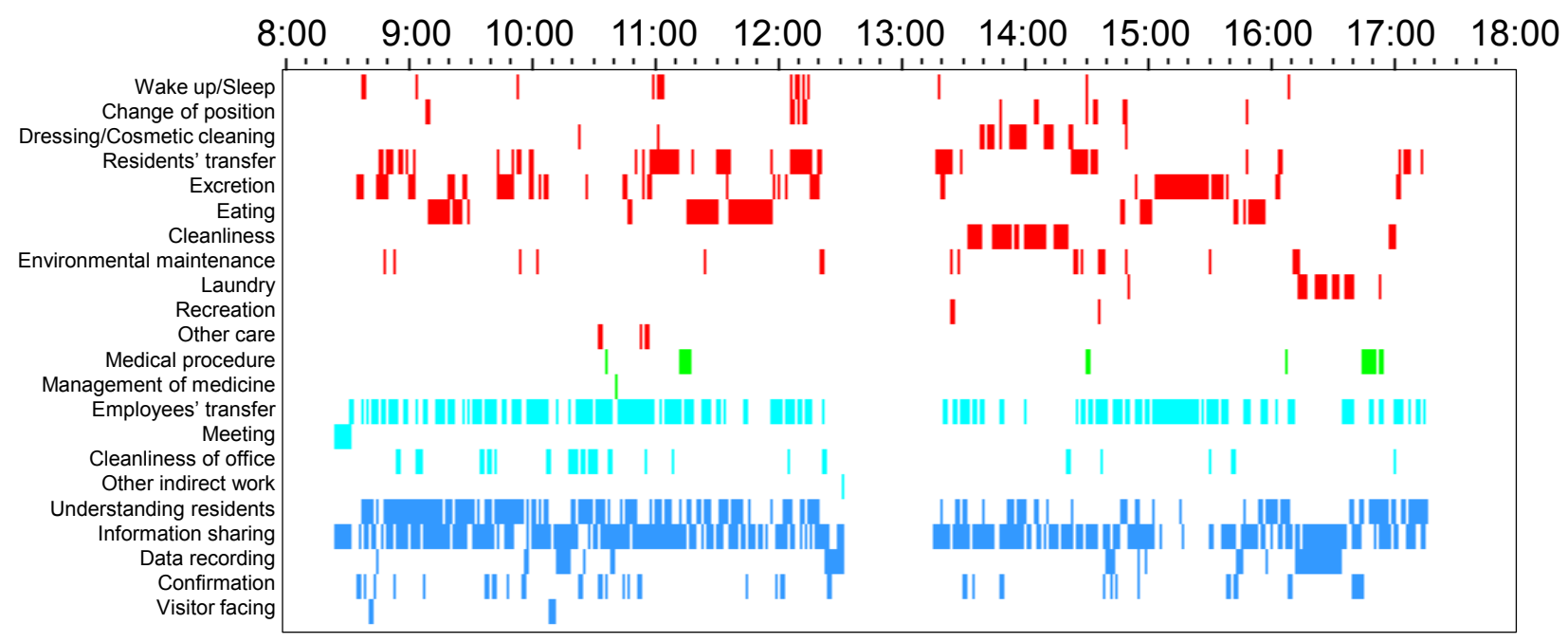

Fig. 4 Nursing-care service process visualized by time-line mode: Transition of a care worker's behaviors. The transition of care worker's behaviors was expressed by colored bars in chronological order. They were quickly changed.

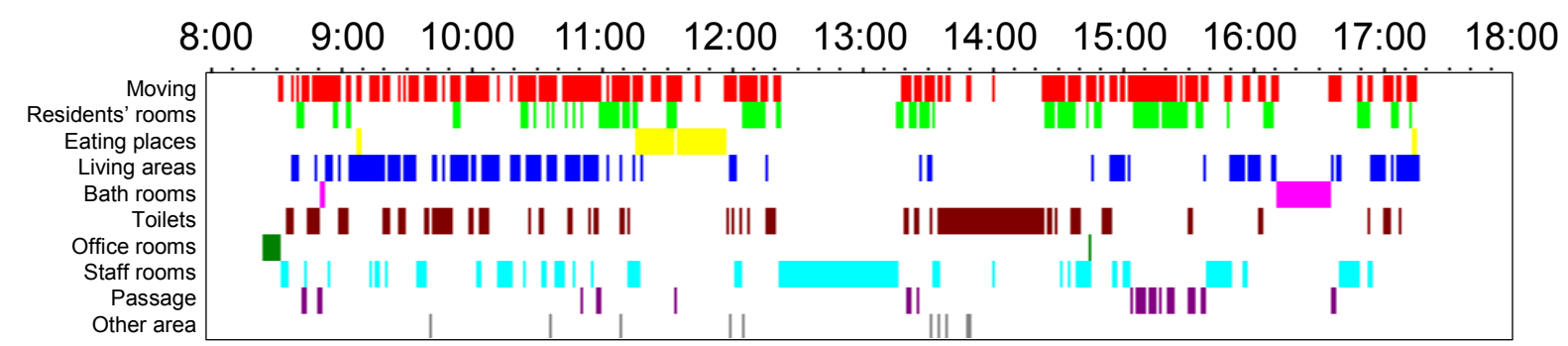

Fig. 5 Nursing-care service process visualized by time-line mode: Transition of a care worker's locations. The transition of care worker's locations was expressed by colored bars in chronological order. 
ある状態が中断され，別の状態に遷移したのち，短時間のうちに元の状態が再開すると「割り込みプロセス」と なる．本実験結果から，同時に複数の状態への遷移や短時間の中断と復帰が確認され，「並行プロセス」およ び「割り込みプロセス」が表現できることを確認した。また，本論文では図示を割愛したが，全ての実験対象 者の介護プロセスは異なっており, 同様のサービスを提供する場合においても, 多様な介護プロセスがあり, 提案手法によって，その多様性を表現できることを確認した。ささら，図 4 では縦軸に介護施設従業員の行 動分類コードの目的・状況層の項目を使用したが，縦軸を見たい行動の階層に設定したり，縦軸を行動以外 の属性に設定することで，場所やサービス対象者の変化も視覚的に確認することができる，例えば，縦軸を 場所にした場合, 図 5 のように居室を訪問した時刻や場所の遷移を表現できる. 以上より, 介護施設従業員 の行動分類コード, 状態遷移による介護プロセス, タイムライン表示による可視化を組み合わせることで, 介護士がどの時間にどのような状態であったかを視覚的に理解できることが確認された。

統計表示とは, 介護プロセスの任意の属性について, 指定した範囲でそれぞれどの程度の時間を費やした か, それが計測時間に対してどの程度の割合か, 行動ごとの比率を統計的に算出しグラフ表示で可視化する 方法である. 図 4 に示した和光苑介護士の介護プロセスを図 6 に統計表示で示す. 図 6 より従業員間の情報 共有, 利用者理解, 従業員の移動の順で費やした時間が多く, その 3 行動で 1 日の約 50\%の割合を占めてい たことが分かる. 図 6 でも目的・状況層で統計処理を行っているが，タイムライン表示同様に階層や属性を 変えて比較することも可能である.

次に, 本結果を計測対象者および施設責任者に対して提示し, 介護プロセスの可視化の効果・可視化方法 の有効性についてインタビュー調査を行った. その結果, タイムライン表示, 統計表示に対して良好な反応 が見られ，ほとんどの従業員から提案手法が自身の介護プロセスの見直しや介護プロセスの設計，従業員の 教育支援に有効であるとの評価を得られた.

以上より, 提案手法を用いることで, 介護プロセスの計測と記述が達成され, 従業員が理解しやすい形で 行動がどのように遷移し, どの程度の時間を費やしたか, それが計測時間に対してどの程度の割合であった かなど, 介護プロセスを可視化することができた，一方で，従業員のニーズに合わせた可視化手法，評価指 標のさらなる提案が今後の課題として残った。

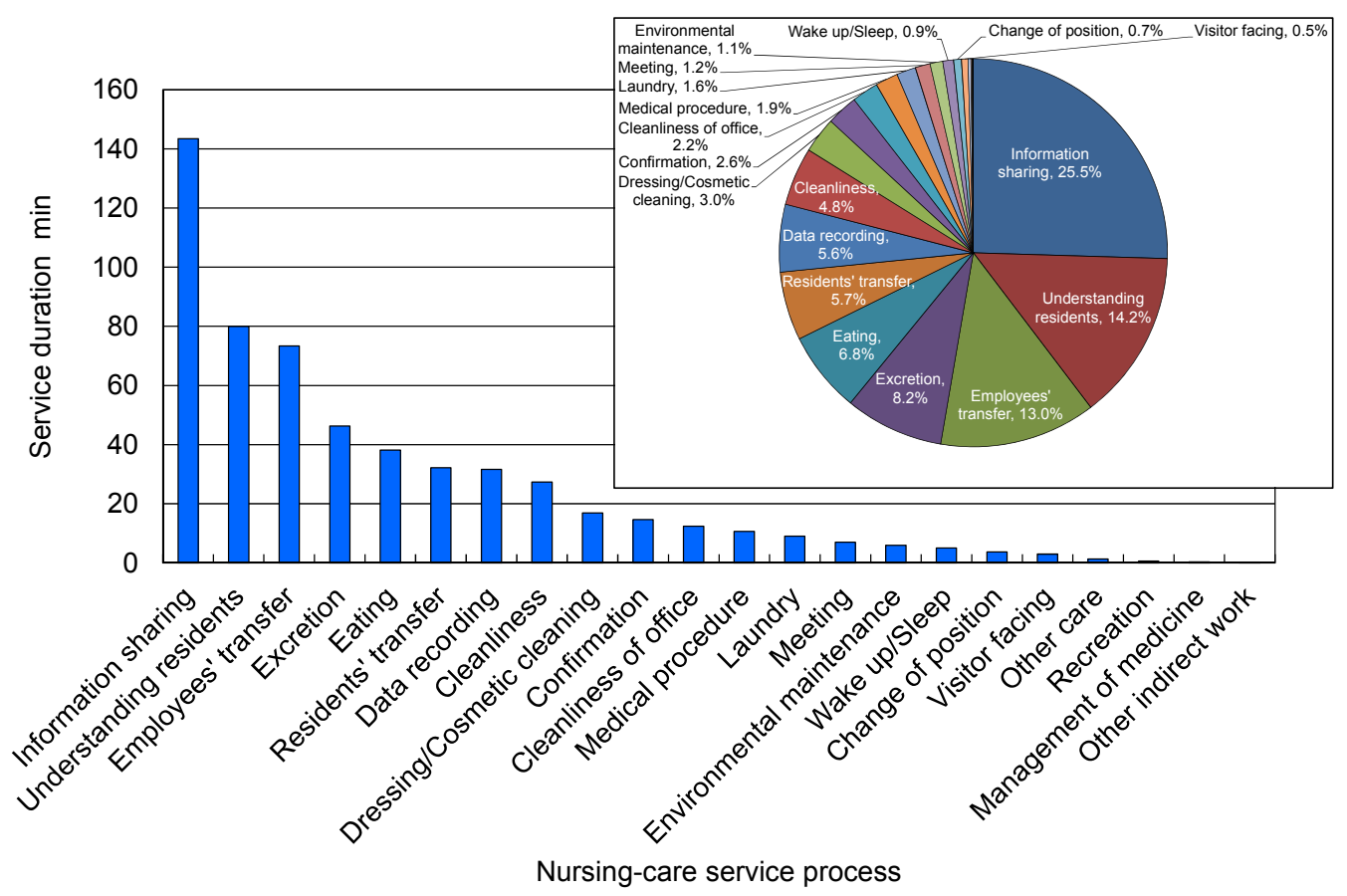

Fig. 6 Nursing-care service process visualized by statistical mode: Time and ratio of service duration of a care worker. The results of statistical processing were expressed. The care worker spent more than half of her work time in sharing information with other employees, understanding residents' condition and her own transfers. 


\section{$4 \cdot 3$ 介護プロセスへの介入効果の可視化}

和光苑では介護士や看護師の専門職従業員による長時間の間接業務が，以前より課題となっていたそそこ で，間接業務を短時間化し，入居者との接点時間を増加させるため，介護士および看護師の記録作業の一部 を関連施設の専門職員に委託することになった。そこで，介護プロセスの変化とその効果の定量評価に対す る提案手法の有効性を検討寸るため, 介護プロセス変更の前後間の介護プロセスを比較した.

図 7 に同一業務を担当した介護士の介護プロセスを統計表示で示す．本結果より，記録作成に費やした割 合が $43.2 \%$ から $5.68 \%$ 一と 37.6 points 減少(約 0.13 倍)し，その時間が排泄介助や移動介助，入居者理解とい った直接的な介護サービスの時間，介護士自身の移動時間や記録の確認時間に費やされたことが分かる．特 に，直接的な介護サービスの時間は介護プロセスの変更によって $35.6 \%$ \%ら $57.8 \%$ \%と 22.2 points 増加(約 1.6 倍)したことが示され, 従業員と利用者の顧客接点時間の増加が確認され, 他の従業員でも同様の結果を 得ることができた，以上より，従来のサービス現場では，サービスプロセスの変更やサービスプロセスへの 介入に対して主観的な評価を行うことが多かったが，提案手法による介護プロセスの計測と可視化を行うこ とで, 介護プロセスの変更による効果を客観的かつ視覚的に評価でき, 提案手法の有効性が確認された.

\section{$4 \cdot 4$ 介護プロセスの評価}

業務改善を目的とした介護プロセスの分析における提案手法の有効性を検討するため, 和光苑で後期に計 測した介護プロセスに対して統計処理を行い, 介護プロセスにおける改善ポイントを分析した。その結果, 図 8 に示寸通り，和光苑では従業員間の情報共有に $14.2 \%$, 記録作業に $7.52 \%$, 記録の確認に $3.23 \%$ の時間 を費やしており，これらを合計すると，従業員 1 人当たり平均で 1 日の $25.0 \%$ の時間を情報に関連する行動 に費やしていたことが明らかになった，筆者らは，1 日の業務において情報に関連する行動が占める割合は 他の行動と比べて高いため, 効率化によって時間削減できる余地が大きく, 同行動の改善がサービス生産性 の改善への寄与が高いと考えた。

そこで, 和光苑に本分析結果をフィードバックしたところ, 情報共有手段の改善に関する議論へと発展し, 新しいIT システムの開発と導入が決定した. 新システムの導入により, 記録と確認に要する時間の短縮が見 込まれており, 介護プロセスの改善が期待されている(福原他, 2013; 中島他, 2012). 以上より, 提案手法に よる介護プロセスの計測と可視化により, 介護プロセスの分析と改善点が特定され，分析結果に基づいた介 護プロセスの改善，設計が行われることが確認され，提案手法が有効に機能したと考える.

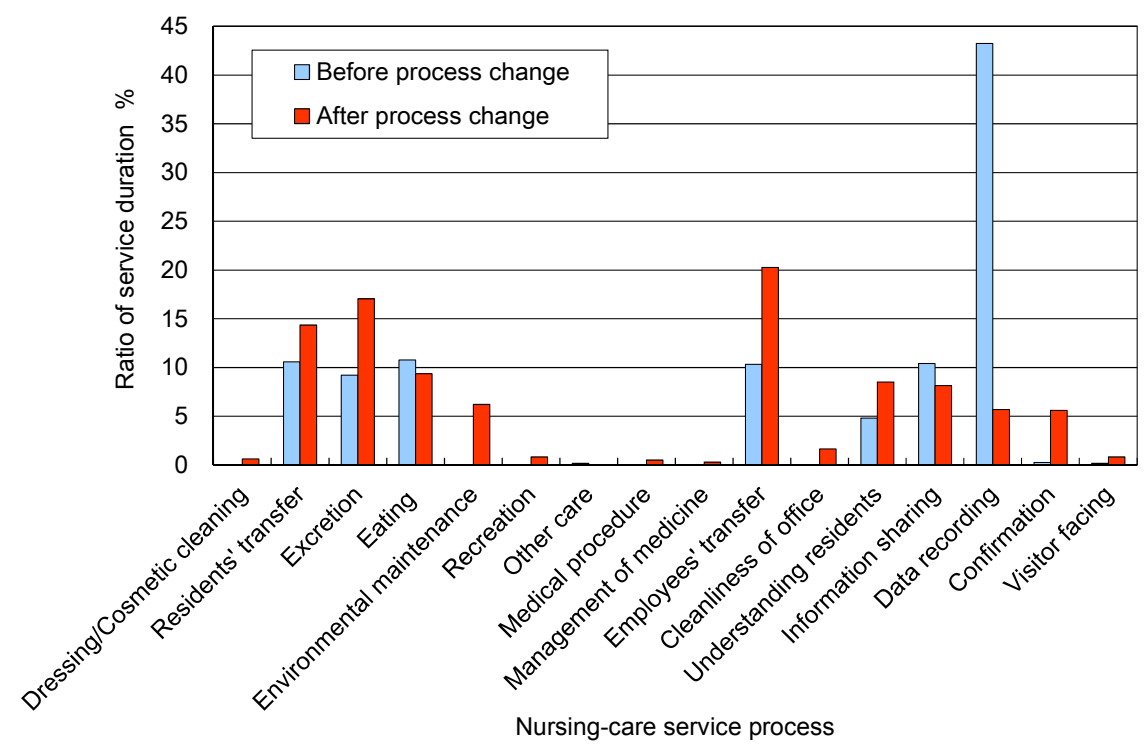

Fig. 7 Comparison of nursing-care service process between before and after the process change. The data recording was reduced by 37.6 points. And, the rate of direct service such as excretion and residents' understanding increased 22.2 points, from $35.6 \%$ to $57.8 \%$. 


\section{5. 結 言}

本研究では，介護サービスにおけるサービス生産性向上を目指し，介護プロセスの記述手法を新規に構築し た. 具体的には，介護施設従業員への行動観察，インタビューを行い，従業員の行動として 145 種類の行動 を抽出した.それらの行動をサービスの種類，目的・状況，行動の 3 層構造で行動分類することで，介護施 設従業員の行動分類コードを構築した。 また，介護プロセスの特徵である「並行性」「不定性」「多様性」を 表現するため，従業員の状態を「id」「行動」「開始時刻」「終了時刻」「場所」「サービス対象者」「コスト」「詳 細な作業内容」の 8 属性で記述し，一連のサービスにおける従業員の状態の集合を「介護プロセス」として記述 した. 最後に，20 名の介護施設従業員の行動計測を実施し，介護施設従業員の行動分類コードが介護施設従 業員の行動の $96.9 \%$ を網羅していることを確認した. さらに，15 名の介護施設従業員の介護プロセスについ て計測と可視化を行い，提案手法が介護プロセスの評価および改善，設計に有効であることを示した。

今後は, 計測の自動化や評価指標, 可視化手法の改良, 現場への導入手法の構築などを行い, 介護プロセ スの計測，可視化する仕組みをサービス現場に埋め込むことを目指す。これにより，図 9 のように，計測一 可視化 $\rightarrow$ー ドバック ササービスプロセスの設計というサイクルを回し続け，持続的なサービス生産性の 向上の仕組みを構築する。

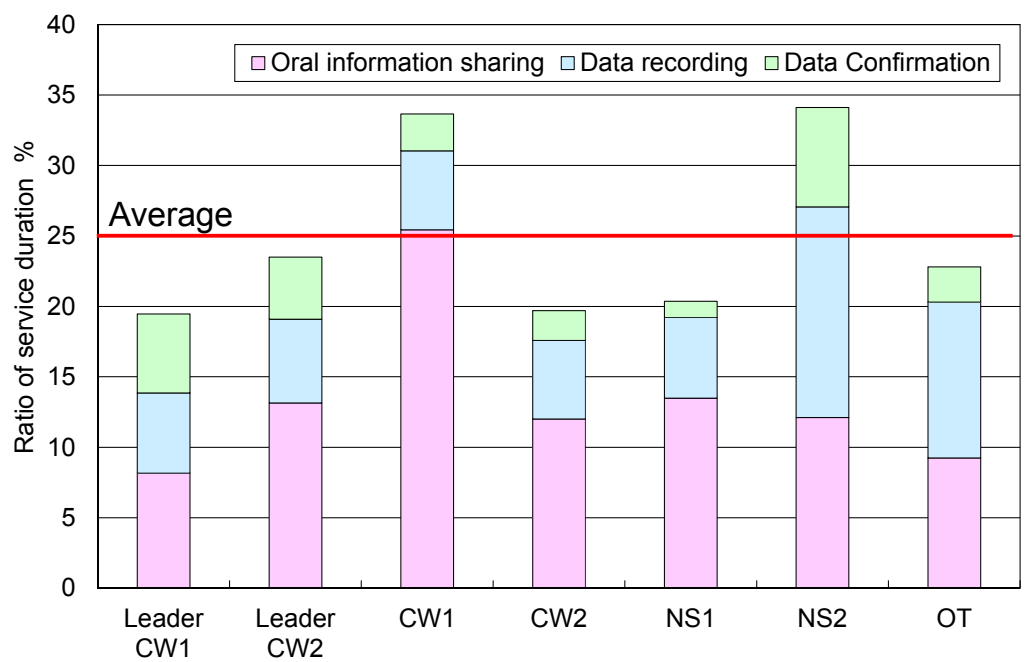

Fig. 8 Ratio of service duration for information sharing, data recording and data confirmation (CW: Care Worker, NS: Nurse, OT: Occupational Therapist). The employees spent $25.0 \%$ of work time in average for information sharing, record and confirmation.

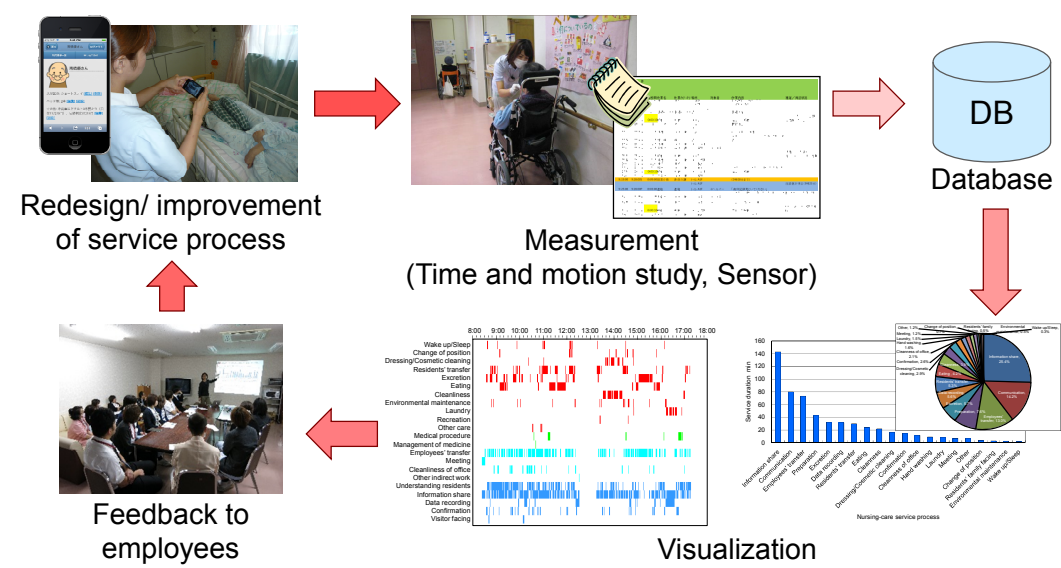

Fig. 9 Sustainable cycle of nursing-care service process. The cycle of measurement, visualization, feedback and redesign of service process is expected to improve service productivity. 


\section{謝 辞}

本研究の一部は平成 23 年度経済産業省委託事業 次世代高信頼・省エネ坬型 I T 基盤技術開発・実証事業（サー ビス工学研究開発分野）「本格研究による人起点のサービス工学基盤技術開発」として実施されました．また，本 研究にご協力頂きました社会医療法人財団 董仙会, 介護老人保健施設 和光苑, 株式会社 スーパー・コート, 介 護付有料老人ホーム スーパー・コート平野, 有料老人ホーム スーパー・コート東大阪みと, 高齢者住宅 スーパ ー・コート南花屋敷, 株式会社太平洋シルバーサービス, 介護付有料老人ホーム シルバーシティ武蔵境, 社会福 祉法人ウェルネスケア, 特別養護老人ホーム いづテラス, 社会福祉法人ひまわりの会, デイサービスセンターひ まわり，株式会社高良，デイサービス ゆたか，株式会社 富士データシステムに御礼申し上げます.

\section{文献}

福原知宏, 中島正人, 三輪洋靖, 濱崎雅弘, 西村拓一, 情報推薦を用いた高齢者介護施設向け申し送り業務支援シ ステム, 人工知能学会論文誌, Vol.28, No.6 (2013), pp.468-479.

原辰徳, 新井民夫, 下村芳樹, サービス工学の提案 (第 3 報, サービス活動の導入による機能・属性表現の統合), 日 本機械学会論文集 C 編, Vol. 4, No.745 (2008), pp.229-238.

原辰徳, 新井民夫，下村芳樹，サービスづくりのための対象表現手法，計測と制御, Vol.48, No.5 (2009), pp.423-428. 要介護認定調査検討会, 第 3 回要介護認定調査検討会資料 (2007).

日本看護科学学会 看護学学術用語検討委員会(編), 看護行為用語分類 (2005), 文唱堂印刷.

笠原聡子, 石井豊恵, 沼崎穂高, 浦梨枝子, 馬醫世志子, 輪湖史子, 横内光子, 鈴木珠水, 大野ゆう子, タイムスタ ディとはその背景と特徴, 看護研究, Vol.37, No.4 (2004a), pp.11-22.

笠原聡子, 石井豊恵, 沼崎穂高, 中村亜紀, 聲声高英代, 原内一, 稲邑清也, 大野ゆう子, タイムスタディの実施, 看護研究, Vol.37, No.4 (2004b), pp.23-31.

笠原聡子, 看護業務の中断に着目したプロセスモデリング, 生体医工学, Vol.48, No.6 (2010), pp.530-535.

Kourogi, M., Kurata, T. and Ishikawa, T., A Method of Pedestrian Dead Reckoning Using Action Recognition, Proceedings of 2010 IEEE/ION Position Location and Navigation Symposium (2010), pp.85-89.

國定美香, 介護保険施設の介護職員における介護時間の評価 -介護支給時間から介護労働時間と非特定介護時間 の比較-, 厚生の指標, Vol.57, No.2 (2010), pp.13-18.

蔵田武志, 天目隆平, 従業員行動計測によるサービスプロセスリエンジニアリング, 人工知能学会誌, Vol.28, No.2 (2013), pp.238-244.

松波晴人, 行動観察によるサービス現場改善（飲食店、鉄道、ホテル），人間工学, Vol. 46, 特別号 (2010), pp.44-45. 厚生労働省, 平成 23 年介護サービス施設・事業所調査の概況 (2013), p.1.

Miwa, H., Fukuhara, T. and Nishimura, T., Service process visualization in nursing-care service using state transition model, Advances in the Human Side of Service Engineering (2012), pp. 3-12.

三輪洋靖, 福原知宏, 中島正人, 西村拓一, 介護サービスにおおる現場参画型のサービスプロセスの設計, 日本機 械学会 2012 年度年次大会論文集 (2012), W121003.

持丸正明, 本格研究による人起点のサービス工学基盤技術開発事業の概要, 電子情報通信学会技術研究報告, SWIM (ソフトウェアインタプライズモデリング研究会), Vol.111, No.189 (2011), pp.1-6.

中島正人, 福原知宏, 三輪洋靖, 西村拓一, 介護サービスにおける申し送り支援システムの開発, モバイル学会誌, Vol.2, No.2 (2012), pp.39-48.

沼崎穂高, 笠原聡子, 石井豊恵, 古川有香, 飯沼正博, 国府裕子, 北村有子, 萩本明子, 杂唯公美子, 原内一, 稲邑 清也, 大野ゆう子, タイムスタディにおけるデータ管理, 看護研究, Vol.37, No.4 (2004), pp.319-332.

Pigage, L.C. and Tucker, J.L., Motion and time study, The University of Illinois Bulletin, Vol.51, No.73 (1954).

坂尾知彦, 原辰徳, 渡辺健太郎, 下村芳樹, サービス工学の提案 (第 2 報, サービス工学のためのサービス設計手 法)，日本機械学会論文集 C 編, Vol.71, No.708 (2005), pp.184-191.

Scheer, A. W. and Schneider, K., Aris - architecture of integrated information systems, Handbook on architectures of information systems (2006), pp.605-623, Springer Berlin Heidelberg.

清水佐知子, 大野ゆう子, 岩佐真也, 尾島裕子, 林剣煌, 冨澤理恵, 大西喜一郎, 本杉ふじ总, 岡田千鶴, タイムス タディによる看護業務プロセスの可視化, 生体医工学, Vol.48, No.6 (2010), pp.536-541.

下村芳樹, 原辰徳, 渡辺健太郎, 坂尾知彦, 新井民夫, 冨山哲男, サービス工学の提案 (第 1 報, サービス工学のた めのサービスモデル化技法), 日本機械学会論文集 C 編, Vol.71, No.702 (2005), pp.315-322. 
サービス産業のイノベーションと生産性に関する研究会, サービス産業におけるイノベーションと生産性向上に 向けた報告書 (2007), p.25, 経済産業省.

Takenaka, T., Koshiba, H. and Motomura, Y., Development strategy of service engineering for retail and restaurant services, The Philosopher's Stone for Sustainability (Proceedings of the 4th CIRP International Conference on Industrial Product Service Systems) (2012), pp.121-124.

Tateyama, T., Kimita, K., Watanabe, K., Chiba, R. and Shimomura, Y., A Service Flow Simulation Method Using Multi-aspect Scene Transition Nets (STNs) Modeling, The Philosopher's Stone for Sustainability (Proceedings of the 4th CIRP International Conference on Industrial Product Service Systems) (2012), pp.297-302.

van der Aalst, W.M.P., Formalization and verification of event-driven process chains, Information and Software Technology, Vol.41, Issue 10 (1999), pp.639-650.

White, S. A., Introduction to BPMN, Business Process Trends (2004), pp.1-11.

世界保健機構 (WHO, World Health Organization), 厚生労働省 (翻訳), ICF 国際生活機能分類 -国際障害分類改訂 版- (2008), 中央法規出版.

\section{References}

Fukuhara, T., Nakajima, M., Miwa, H., Hamasaki, M. and Nishimura T., Design and implementation of a handover support system based on information recommendation in nursing homes, Journal of the Japanese Society for Artificial Intelligence, Vol.28, No.6 (2013), pp.468-479 (in Japanese).

Hara, T., Arai, T. and Shimomura, Y., Proposal of the Service Engineering (3rd Report, Integrating Function-Attribute Representation of Service by Introducing Service Activity, Transactions of the Japan Society of Mechanical Engineers, Series C, Vol. 4, No.745 (2008), pp.229-238 (in Japanese).

Hara, T., Arai, T. and Shimomura, Y., Object Representation for Service Development, Journal of the Society of Instrument and Control Engineers, Vol.48, No.5 (2009), pp.423-428 (in Japanese).

Investigation review committee on certification of long-term care need*, 3rd report on certification of long-term care need ${ }^{*}$ (2007) (in Japanese).

Japan Academy of Nursing Science, Classification of nursing practice (2005), Bunshodo Printing (in Japanese).

Kasahara, S., Ishii, A., Numasaki, H., Ura, R., Bai, Y., Wako, F., Yokouchi, M., Suzuki, T. and Ohno, Y., What is Time and Motion Study? Historical Background, The Japanese Journal of Nursing Research, Vol.37, No.4 (2004a), pp.11-22 (in Japanese).

Kasahara, S., Ishii, A., Numasaki, H., Nakamura, A., Koedaka, H., Harauchi, H., Inamura, K. and Ohno, Y., Implementation of Time and Motion Study, The Japanese Journal of Nursing Research, Vol.37, No.4 (2004b), pp.23-31 (in Japanese).

Kasahara, S., Work process modeling for interruptions in nursing workflow, Transaction of Japanese Society for Medical and Biological Engineering, Vol.48, No.6 (2010), pp.530-535 (in Japanese).

Kourogi, M., Kurata, T. and Ishikawa, T., A Method of Pedestrian Dead Reckoning Using Action Recognition, Proceedings of 2010 IEEE/ION Position Location and Navigation Symposium (2010), pp.85-89.

Kunisada, M., Evaluation for nursing-care service time of employees in nursing-care facilities ${ }^{*}$, Journal of Health and Welfare Statistics, Vol.57, No.2 (2010), pp.13-18 (in Japanese).

Kurata, T. and Tenmoku, R., Service Process Reengineering Based on Behavior Measurement of Employees, Journal of the Japanese Society for Artificial Intelligence, Vol.28, No.2 (2013), pp.238-244 (in Japanese).

Matsunami, H., Service Improvement by Behavior Observation (at Restaurant, Railway Station, and Hotel), The Japanese Journal of Ergonomics, Vol. 46 Supplement (2010), pp.44-45 (in Japanese).

Ministry of Health, Labour and Welfare, Overview of survey on nursing-care service facilities in $2011^{*}$ (2013), p.1 (in Japanese).

Miwa, H., Fukuhara, T. and Nishimura, T., Service process visualization in nursing-care service using state transition model, Advances in the Human Side of Service Engineering (2012), pp. 3-12.

Miwa, H., Fukuhara, T., Nakajima M. and Nishimura, T., Design of Service Process at Nursing-care Service by Service Filed Participatory Development, Proceedings of Mechanical Engineering Congress, 2012 Japan (2012), W121003 (in Japanese).

Mochimaru, M., A research project for human centered service engineering, IEICE Technical Report, SWIM2011-11, Vol.111, No.189 (2011), pp.1-6 (in Japanese). 
Nakajima, M., Fukuhara, T., Miwa, H. and Nishimura, T., Development of a supporting system for handing-over at nursing-care facilities, Journal of Mobile Interactions, Vol.2, No.2 (2012), pp.39-48 (in Japanese).

Numasaki, H., Kasahara, S., Ishii, A., Furukawa, Y., Iinuma, M., Kou, H., Kitamura, Y., Hagimoto, A., Saika, K., Harauchi, H., Inamura, K. and Ohno, Y., Data Management in Time and Motion Study, The Japanese Journal of Nursing Research, Vol.37, No.4 (2004), pp.319-332 (in Japanese).

Pigage, L.C. and Tucker, J.L., Motion and time study, The University of Illinois Bulletin, Vol.51, No.73 (1954).

Sakao, T., Hara, T., Watanabe, K. and Shimomura, Y., Proposal of the Service Engineering (2nd Report, Service Design Methodology for Service Engineering), Transactions of the Japan Society of Mechanical Engineers, Series C, Vol.71, No.708 (2005), pp.184-191 (in Japanese).

Scheer, A. W. and Schneider, K., Aris - architecture of integrated information systems, Handbook on architectures of information systems (2006), pp.605-623, Springer Berlin Heidelberg.

Shimizu, S., Ohno, Y., Iwasa, M., Ojima, H., Lin, J., Tomizawa, R., Ohnishi, K., Motosugi, F. and Okada, C., Visualizing Nursing Work Process using Time and Motion Study, Transaction of Japanese Society for Medical and Biological Engineering, Vol.48, No.6 (2010), pp.536-541 (in Japanese).

Shimomura, Y., Hara, T., Watanabe, K., Sakao, T., Arai, T. and Tomiyama, T., Proposal of the Service Engineering (1st Report, Service Modeling Technique for the Service Engineering), Transactions of the Japan Society of Mechanical Engineers, Series C, Vol.71, No.702 (2005), pp.315-322 (in Japanese).

Study group on innovation and service productivity in service industry*, Report on innovation and service productivity improvement in service industry $^{*}$ (2007), p.25, Ministry of Economy, Trade and Industry (in Japanese).

Takenaka, T., Koshiba, H. and Motomura, Y., Development strategy of service engineering for retail and restaurant services, The Philosopher's Stone for Sustainability (Proceedings of the 4th CIRP International Conference on Industrial Product Service Systems) (2012), pp.121-124.

Tateyama, T., Kimita, K., Watanabe, K., Chiba, R. and Shimomura, Y., A Service Flow Simulation Method Using Multi-aspect Scene Transition Nets (STNs) Modeling, The Philosopher's Stone for Sustainability (Proceedings of the 4th CIRP International Conference on Industrial Product Service Systems) (2012), pp.297-302.

van der Aalst, W.M.P., Formalization and verification of event-driven process chains, Information and Software Technology, Vol.41, Issue 10 (1999), pp.639-650.

White, S. A., Introduction to BPMN, Business Process Trends (2004), pp.1-11.

World Health Organization (WHO), Ministry of Health, Labour and Welfare (Translation), ICF (International Classification of Functioning, Disability and Health) (2008), Chuohoki Publishing (in Japanese).

* is translated by the authors.

Appendix 1 Task classification code for nursing-care service (Part 1)

\begin{tabular}{|c|c|c|c|}
\hline $\begin{array}{c}\text { Service type } \\
\text { (サービスの種類) }\end{array}$ & $\begin{array}{l}\text { Purpose / Situation } \\
\text { (目的 } \cdot \text { 状況) }\end{array}$ & $\begin{array}{l}\text { Operation } \\
\text { (行動) } \\
\end{array}$ & $\begin{array}{c}\text { Code } \\
(\text { コード })\end{array}$ \\
\hline \multirow{18}{*}{$\begin{array}{l}\text { Care } \\
\text { (介護) }\end{array}$} & \multirow{2}{*}{$\begin{array}{l}\text { Wake up / Sleep } \\
\text { (起床•就寝) }\end{array}$} & Wake up assistance (起床介助) & $\mathrm{C} 0101$ \\
\hline & & Sleep assistance (就寝介助) & $\mathrm{C} 0102$ \\
\hline & \multirow{2}{*}{$\begin{array}{l}\text { Change of position } \\
\text { (体位変換) }\end{array}$} & Change of position (体位変換) & $\mathrm{C} 0201$ \\
\hline & & Seat position adjustment (リクライニング調整) & $\mathrm{C} 0202$ \\
\hline & \multirow{2}{*}{$\begin{array}{c}\text { Dressing / Cosmetic cleaning } \\
\text { (更衣·整容) }\end{array}$} & Dressing assistance (更衣介助) & $\mathrm{C} 0301$ \\
\hline & & Cosmetic cleaning assistance (整容介助) & $\mathrm{C} 0302$ \\
\hline & \multirow{4}{*}{$\begin{array}{l}\text { Residents' transfer } \\
\text { (移動) }\end{array}$} & Wheel chair guidance (車い寸誘導) & $\mathrm{C} 0401$ \\
\hline & & Walking assistance (歩行介助) & $\mathrm{C} 0402$ \\
\hline & & Transfer motion assistance (移乗介助) & $\mathrm{C} 0403$ \\
\hline & & Standing assistance (立位介助) & $\mathrm{C} 0404$ \\
\hline & \multirow{3}{*}{$\begin{array}{l}\text { Excretion } \\
\text { (排泄) }\end{array}$} & Excretion assistance (排泄介助) & $\mathrm{C} 0501$ \\
\hline & & Napkin change (おむつ交換) & $\mathrm{C} 0502$ \\
\hline & & Hand-wash assistance (手洗い介助) & $\mathrm{C} 0503$ \\
\hline & \multirow{5}{*}{$\begin{array}{l}\text { Eating } \\
\text { (食事) }\end{array}$} & Eating assistance (食事介助) & $\mathrm{C} 0601$ \\
\hline & & Drinking assistance (飲水介助) & $\mathrm{C} 0602$ \\
\hline & & Delivery of dish (配膳) & $\mathrm{C} 0603$ \\
\hline & & Collection of dish (下膳) & $\mathrm{C} 0604$ \\
\hline & & Cooking assistance (調理介助) & $\mathrm{C} 0605$ \\
\hline
\end{tabular}


Appendix 2 Task classification code for nursing-care service (Part 2)

\begin{tabular}{|c|c|c|c|}
\hline $\begin{array}{c}\text { Service type } \\
\text { (サービスの種類) } \\
\end{array}$ & $\begin{array}{c}\text { Purpose / Situation } \\
\text { (目的.状況) }\end{array}$ & $\begin{array}{l}\text { Operation } \\
\text { (行動) }\end{array}$ & $\begin{array}{c}\text { Code } \\
(\text { コード })\end{array}$ \\
\hline \multirow{31}{*}{$\begin{array}{l}\text { Care } \\
\text { (介護) }\end{array}$} & \multirow{12}{*}{$\begin{array}{l}\text { Cleanliness } \\
\text { (清潔) }\end{array}$} & Bath assistance (入浴介助) & $\mathrm{C} 0701$ \\
\hline & & Foot bath assistance (足浴介助) & $\mathrm{C} 0702$ \\
\hline & & Face-wash assistance (洗面介助) & $\mathrm{C} 0703$ \\
\hline & & Bed bath (清拭) & $\mathrm{C} 0704$ \\
\hline & & Genital wash (陰部洗浄) & $\mathrm{C} 0705$ \\
\hline & & Oral care (口腔ケア) & $\mathrm{C} 0706$ \\
\hline & & Cleaning the ears (耳垢除去) & $\mathrm{C} 0707$ \\
\hline & & Nail care (爪切り) & $\mathrm{C} 0708$ \\
\hline & & Shaving (髺剃り) & $\mathrm{C} 0709$ \\
\hline & & Shampoo (洗髮) & $\mathrm{C} 0710$ \\
\hline & & Hand-wash assistance (手洗い介助) & $\mathrm{C} 0711$ \\
\hline & & Gargle assistance (うがい介助) & $\mathrm{C} 0712$ \\
\hline & \multirow{8}{*}{$\begin{array}{l}\text { Environmental maintenance } \\
\text { (環境整備) }\end{array}$} & Sheet change (シーツ交換) & $\mathrm{C} 0801$ \\
\hline & & Collection of waste (ごみ回収) & $\mathrm{C} 0802$ \\
\hline & & Cleaning up residents' room (居室清掃) & $\mathrm{C} 0803$ \\
\hline & & Confirmation of residents' items (入居者物品確認) & $\mathrm{C} 0804$ \\
\hline & & Temperature control (室温調整) & $\mathrm{C} 0805$ \\
\hline & & Humidity conditioning (調湿) & $\mathrm{C} 0806$ \\
\hline & & Brightness control (調光) & $\mathrm{C} 0807$ \\
\hline & & Air ventilation (換気) & $\mathrm{C} 0808$ \\
\hline & \multirow{2}{*}{$\begin{array}{c}\begin{array}{c}\text { Laundry } \\
\text { (洗濯) }\end{array} \\
\end{array}$} & Laundry (洗濯) & $\mathrm{C} 0901$ \\
\hline & & Collection of cloths (洗濯物回収) & $\mathrm{C} 0902$ \\
\hline & \multirow{2}{*}{ Going out (外出) } & Shopping (買物代行) & $\mathrm{C} 1001$ \\
\hline & & Shopping escort (買物付き添い) & $\mathrm{C} 1002$ \\
\hline & \multirow{5}{*}{$\begin{array}{c}\text { Recreation } \\
\text { (レクリエーション) }\end{array}$} & Body exercise (体操) & $\mathrm{C} 1101$ \\
\hline & & Oral exercise (口腔体操) & $\mathrm{C} 1102$ \\
\hline & & Music (音楽) & $\mathrm{C} 1103$ \\
\hline & & Picture-card show (紙芝居) & $\mathrm{C} 1104$ \\
\hline & & Cooking (料理) & $\mathrm{C} 1105$ \\
\hline & \multirow{2}{*}{$\begin{array}{l}\text { Transportation } \\
\text { (送迎) }\end{array}$} & Transportation (送迎) & $\mathrm{C} 1201$ \\
\hline & & Assistance for vehicle ingress / egress (乗降介助) & $\mathrm{C} 1202$ \\
\hline \multirow{28}{*}{$\begin{array}{l}\text { Nursing } \\
\text { (看護) }\end{array}$} & \multirow{11}{*}{$\begin{array}{l}\text { Medical procedure } \\
\text { (医療処置) }\end{array}$} & Tracheal aspiration (気管吸引) & N0101 \\
\hline & & Wound care (創傷ケア) & N0102 \\
\hline & & Application of ointment (軟膏塗布) & N0103 \\
\hline & & Sterilization (消毒) & N0104 \\
\hline & & Transdermal patch (薬剤貼付) & N0105 \\
\hline & & Intravascular pressure monitoring (血管内圧モニタリング) & N0106 \\
\hline & & Intravenous infusion (点滴静脈内注射) & N0107 \\
\hline & & Management of gastric fistula (胃瘻管理) & N0108 \\
\hline & & Urination management (排尿管理) & N0109 \\
\hline & & Enema clyster (浣腸) & N0110 \\
\hline & & Oxygen therapy (酸素療法) & N0111 \\
\hline & & Oral drug administration (経口与薬) & N0201 \\
\hline & & Tubal drug administration (経管与薬) & N0202 \\
\hline & & Drug delivery (配薬) & N0203 \\
\hline & $\begin{array}{l}\text { Management of medicme } \\
\text { (薬品管理) }\end{array}$ & Ocular instillation (点眼) & N0204 \\
\hline & & Injection (注射) & N0205 \\
\hline & & Suppository administration (坐薬投与) & N0206 \\
\hline & & Availability check (在庫確認) & N0207 \\
\hline & & Measurement of body temperature (体温測定) & N0301 \\
\hline & & Measurement of SpO2 (SpO2測定) & $\mathrm{N} 0302$ \\
\hline & Measurement of vital signs & Measurement of heart rate (脈拍測定) & N0303 \\
\hline & (バイタル測定) & Measurement of blood pressure (血圧測定) & N0304 \\
\hline & & Measurement of body weight (体重測定) & N0305 \\
\hline & & Measurement of vital signs (バイタル測定) & N0306 \\
\hline & Clinical examination & Attendance at clinical examination (診察立ち会い) & N0401 \\
\hline & (診察) & Escort to hospital / clinic (病院付き添い) & N0402 \\
\hline & Bodywork & Massage (マッサージ) & N0501 \\
\hline & (身体機能への直接的働きかけ) & Functional recovery (機能回復) & N0502 \\
\hline & & Range of motion exercise (関節可動域訓練) & R0101 \\
\hline & & Heat therapy (温熱療法) & R0102 \\
\hline & & Gait exercise (歩行訓練) & R0103 \\
\hline & $\begin{array}{l}\text { Physical therapy } \\
\text { (理学療泩) }\end{array}$ & Standing exercise (起立訓練) & R0104 \\
\hline & & Stepping exercise (階段昇降) & R0105 \\
\hline & & Therapeutic exercise (運動訓練) & R0106 \\
\hline Rehabilitation & & Assistance of physical therapists (理学療法補助) & R0107 \\
\hline (リハビリテーション) & & Occupational task (作業課題) & $\mathrm{R} 0201$ \\
\hline & & Calculation exercise (計算課題) & R0202 \\
\hline & & Cognitive exercise (認知課題) & R0203 \\
\hline & $\begin{array}{l}\text { Occupational therapy } \\
\text { (作業療法) }\end{array}$ & Memory exercise (記憶課題) & R0204 \\
\hline & & Art work exercise (芸術課題) & R0205 \\
\hline & & Gaming exercise (遊戯課題) & R0206 \\
\hline & & Assistance of occupational therapists (作業療法補助) & R0207 \\
\hline
\end{tabular}


Appendix 3 Task classification code for nursing-care service (Part 3)

\begin{tabular}{|c|c|c|c|}
\hline $\begin{array}{c}\text { Service type } \\
\text { (サービスの種類) }\end{array}$ & $\begin{array}{c}\text { Purpose / Situation } \\
\text { (目的.状況) }\end{array}$ & $\begin{array}{l}\text { Operation } \\
\text { (行動) }\end{array}$ & $\begin{array}{c}\text { Code } \\
\text { (コード) }\end{array}$ \\
\hline \multirow{5}{*}{$\begin{array}{l}\text { Rehabilitation } \\
\text { (リハビリテーション) }\end{array}$} & \multirow{5}{*}{$\begin{array}{c}\text { Speech and language therapy } \\
\text { (言語聴覚療法) }\end{array}$} & $\begin{array}{c}\text { Speech exercise (表出訓練) } \\
\end{array}$ & R0301 \\
\hline & & Auditory comprehensive exercise (聴覚的理解訓練) & R0302 \\
\hline & & Swallowing test (蕜下機能評価) & R0303 \\
\hline & & Indirect swallowing exercise (間接的曣下訓練) & R0304 \\
\hline & & Direct swallowing exercise (直接的嬹下訓練) & R0305 \\
\hline \multirow{4}{*}{$\begin{array}{l}\text { Care management } \\
\text { (介護支援) }\end{array}$} & \multirow{4}{*}{$\begin{array}{l}\text { Care planning } \\
\text { (ケアプラン) }\end{array}$} & Care planning (ケアプラン作成) & $\mathrm{P} 0101$ \\
\hline & & Conference (カンファレンス) & $\mathrm{P} 0102$ \\
\hline & & Monitoring (モニタリング) & $\mathrm{P} 0103$ \\
\hline & & Assessment (アセスメント) & $\mathrm{P} 0104$ \\
\hline \multirow{13}{*}{$\begin{array}{l}\text { Food and nutrition } \\
\text { (食事·栄養) }\end{array}$} & \multirow{6}{*}{$\begin{array}{l}\text { Nutritional management } \\
\text { (栄養管理) }\end{array}$} & Nutritional care planning (栄養ケア計画作成) & F0101 \\
\hline & & Conference (カンファレンス) & F0102 \\
\hline & & Monitoring (モニタリング) & F0103 \\
\hline & & Assessment of nutritional care (栄養アセスメント) & F0104 \\
\hline & & Screening of nutritional care (栄養スクリーニング) & F0105 \\
\hline & & Consultation of food and nutrition (栄養食事相談) & F0106 \\
\hline & \multirow{4}{*}{$\begin{array}{l}\text { Meal service } \\
\text { (給食) }\end{array}$} & Meal menu planning (献立作成) & F0201 \\
\hline & & Cooking (調理) & F0202 \\
\hline & & Counting meal set (食数管理) & F0203 \\
\hline & & Procurement of ingredient (食材調達) & F0204 \\
\hline & \multirow{3}{*}{$\begin{array}{l}\text { Hygiene management } \\
\text { (衛生管理) }\end{array}$} & Physical condition management (体調管理) & F0301 \\
\hline & & Food management (食材管理) & F0302 \\
\hline & & Equipment management (設備管理) & F0303 \\
\hline \multirow{8}{*}{$\begin{array}{l}\text { Indirect work } \\
\text { (間接業務) }\end{array}$} & \multirow{3}{*}{$\begin{array}{l}\text { Employees' transfer } \\
\text { (移動) }\end{array}$} & Employees' transfer (移動) & G0101 \\
\hline & & Waiting (待機) & G0102 \\
\hline & & Conveyance (運搬) & G0103 \\
\hline & \multirow{3}{*}{$\begin{array}{l}\text { Meeting } \\
\text { (会議) }\end{array}$} & Morning meeting (朝礼) & G0201 \\
\hline & & Evening meeting (夕礼) & G0202 \\
\hline & & Meeting (会議) & G0203 \\
\hline & \multirow{2}{*}{$\begin{array}{c}\text { Cleanliness of office } \\
\text { (清掃) }\end{array}$} & Cleaning up common space (共用部清掃) & G0301 \\
\hline & & Arrangement (整理・整頓) & G0302 \\
\hline $\begin{array}{c}\text { Other work } \\
\text { (その他の業務) }\end{array}$ & $\begin{array}{c}\text { Other work } \\
\text { (その他の業務) }\end{array}$ & Other work (その他の業務) & OS6T1 \\
\hline $\begin{array}{l}\text { Out of work } \\
\text { (業務外) }\end{array}$ & $\begin{array}{l}\text { Break } \\
\text { (休眀) }\end{array}$ & Break (休㮩) & B0101 \\
\hline $\begin{array}{c}\text { Measurement error } \\
\text { (エラー) }\end{array}$ & $\begin{array}{c}\text { Measurement error } \\
\text { (エラー) }\end{array}$ & Measurement error (エラー) & EE1E1 \\
\hline
\end{tabular}

Appendix 4 Task classification code for nursing-care service (common items to all "service types")

\begin{tabular}{|c|c|c|c|}
\hline $\begin{array}{c}\text { Service type } \\
\text { (サービスの種類) }\end{array}$ & $\begin{array}{l}\text { Purpose / Situation } \\
\text { (目的・状況) }\end{array}$ & $\begin{array}{l}\text { Operation } \\
\text { (行動) } \\
\end{array}$ & $\begin{array}{c}\text { Code } \\
\text { (コード) }\end{array}$ \\
\hline \multirow{18}{*}{$\begin{array}{c}\text { Service type } \\
\text { (サービスの種類) }\end{array}$} & \multirow{5}{*}{$\begin{array}{l}\text { Understanding residents } \\
\text { (利用者理解) }\end{array}$} & Communicate care (声掛け) & $*$ S101 \\
\hline & & Active listening (傾聴) & *S102 \\
\hline & & Observation (見守り) & $*$ S103 \\
\hline & & Confirmation of residents' condition (入居者状態確認) & *S104 \\
\hline & & Response to nurse call (ナースコール対応) & $*$ S105 \\
\hline & \multirow{4}{*}{$\begin{array}{c}\text { Information sharing } \\
\text { (情報共有) }\end{array}$} & Oral information sharing (連絡) & *S201 \\
\hline & & Handing-over (申し送り) & *S202 \\
\hline & & Calling (電話) & *S203 \\
\hline & & Sending and Receiving faxes (FAX送受信) & *S204 \\
\hline & \multirow{3}{*}{$\begin{array}{l}\text { Data recording } \\
\text { (記録作成) }\end{array}$} & Data recording (記録作成) & $*$ S301 \\
\hline & & Calculation (計算) & *S302 \\
\hline & & Printing / copying (印刷・コピー) & *S303 \\
\hline & \multirow{3}{*}{$\begin{array}{l}\text { Confirmation } \\
\text { (確認) }\end{array}$} & Data confirmation (記録確認) & *S401 \\
\hline & & Task confirmation (作業確認) & *S402 \\
\hline & & Equipment confirmation (備品確認) & $*$ S403 \\
\hline & \multirow{2}{*}{$\begin{array}{l}\text { Visitor facing } \\
\text { (来客対応) }\end{array}$} & Family facing (家族対応) & *S501 \\
\hline & & Visitor facing (来客対応) & *S502 \\
\hline & $\begin{array}{c}\text { Other service } \\
\text { (その他のサービス) }\end{array}$ & Other service (その他のサービス) & *S6T1 \\
\hline
\end{tabular}

Appendix 5 Task classification code for nursing-care service (common items to all "purposes and situations")

\begin{tabular}{c|c|c|c}
\hline \hline $\begin{array}{c}\text { Service type } \\
\text { (サービスの種類 })\end{array}$ & $\begin{array}{c}\text { Purpose / Situation } \\
\text { (目的・状況) }\end{array}$ & $\begin{array}{c}\text { Operation } \\
\text { (行動) }\end{array}$ & $\begin{array}{c}\text { Code } \\
(\text { コード) }\end{array}$ \\
\hline Service type & Purpose / Situation & Preparation (準備・片付け) & $* *$ J1 \\
\cline { 3 - 4 }$($ サービスの種類 $)$ & (目的・状況) & Hand-wash (手洗い) & $* * * \mathrm{H} 1$ \\
\cline { 3 - 4 } & & Other (その他) & $* * * \mathrm{~T} 1$ \\
\hline
\end{tabular}

